\title{
Effects of environmental factors on community structure of Leptophlebiidae (Insecta, Ephemeroptera) in Cerrado streams, Brazil
}

\author{
Leandro S. Brasil $1^{1}$, Yulie Shimano ${ }^{2}$, Joana Darc Batista ${ }^{3}$ \& Helena S. R. Cabette ${ }^{4}$ \\ 1. Programa de Pós-Graduação em Ecologia e Conservação, Universidade do Estado de Mato Grosso, Caixa Postal 08, 78690-000 Nova Xavantina, MT, Brasil. (brasil_biologia@hotmail.com). \\ 2. Programa de Pós-Graduação em Zoologia, Universidade Federal do Pará, Rua Augusto Correia, nº1, Bairro Guanabara, 66075-110 Belém, Pará, Brasil. (shimano.yulie@gmail.com) \\ 3. Universidade do Estado de Mato Grosso, Caixa Postal 08, 78690-000 Nova Xavantina, MT, Brasil.(joanadarcb@yahoo.com.br) \\ 4. Departamento de Ciências Biológicas, Universidade do Estado de Mato Grosso, Caixa Postal 08, 78690-000 Nova Xavantina, MT, Brasil.(hcabette@uol.com.br)
}

\begin{abstract}
We analyzed the effects of environmental factors on abundance, species richness, and functional group richness of Leptophlebiidae in 16 sampling points along four Cerrado streams. Across three periods of 2005, we collected 5,492 larvae from 14 species in stream bed substrate. These species belong to three functional feeding groups: scrapers, filtering collectors and shredders. The abundance and species richness were not affected by water quality, but habitat quality related to presence of riparian vegetation had positive effects on the abundance of shredders. Our results add important information on the natural history of the species and functional groups of aquatic insects and also provide relevant data for the monitoring and conservation of streams in the Brazilian Cerrado.
\end{abstract}

KEYWORDS. Aquatic insects; functional feeding groups; environmental changes.

RESUMO. Efeito de fatores ambientais sobre Leptophlebiidae (Insecta: Ephemeroptera) em córregos de Cerrado, Brasil. O efeito de fatores ambientais sobre a abundância, riqueza de espécies e grupos funcionais alimentares de Leptophlebiidae foi analisado em 16 locais pertencentes a quatro córregos de Cerrado, a partir de coletas de substrato em três períodos de 2005. Foram amostradas 5.492 larvas distribuídas em 14 espécies, classificadas em três grupos funcionais alimentares: raspadores, coletores-filtradores e fragmentadores. A abundância e riqueza de espécies não foram afetadas por nenhum dos fatores ambientais investigados, mas a integridade dos hábitats exerceu efeito positivo sobre a abundância dos fragmentadores, consequência da intrínseca interação desses organismos com a mata ciliar. Dessa forma, acreditamos que este trabalho agrega informações bioecológicas sobre as espécies e grupos funcionais de insetos aquáticos e poderá contribuir no monitoramento e conservação de riachos do Cerrado.

PALAVRAS-CHAVE. Insetos aquáticos; grupos funcionais alimentares; alterações ambientais.

Aquatic ecosystems are complex biological systems in which physic-chemical processes influence and are influenced by interspecific interactions (BAE et al., 2011). Anthropogenic disturbances and land use in the drainage basin may impact the aquatic environment during and after the runoff (CABETTE et al., 2010; Dias-SiLva et al., 2010). The removal of riparian vegetation has a negative effect on the input of organic matter, which is the source of energy in small stream ecosystems (Delong \& BRUSVEN, 1994).

Habitat quality is a major factor determining the colonization and establishment of ecological communities in lentic and lotic systems (TATE \& HeInY, 1995). Pollution, eutrophication, siltation, dams, flood control, fisheries and introduction of exotic species contribute directly to the loss of aquatic biodiversity (AgostinHo et al., 2005).

Aquatic insects are among the most commonly used bioindicators of aquatic habitat quality, owing to the key role in organic material cycling in aquatic ecosystems (Bello \& CABRERA, 2001) and crossecosystem linkages between aquatic and the adjacent riparian environment (DA-SILVA et al., 2010).

Mayflies are abundant and diverse aquatic insects in both lentic and lotic environments, especially in streams (BritTAIN, 1982). They are good bioindicators due to their low tolerance to environmental change (Da-Silva \& Domingues, 2009). In most cases, environmental disturbs changes species abundance and composition (e.g. Shimano et al., 2010; Souza et al., 2011). Mayflies also play key roles in transference of materials between aquatic and terrestrial environments through respiration and adult biomass (DA-SiLVA et al., 2010).

Currently, 10 families and 290 species of mayflies are known to occur in Brazil, from which Leptophlebiidae (mayflies) ranks the second most speciose, with 77 species (SAlles et al., 2013). Much attention has been given to taxonomic studies (e.g. DASilva et al., 2002; Salles et al., 2004; Domínguez et al., 2006; PolegatTo \& BATISTA, 2007; BoldRINI et al., 2009). However, ecological data about these organisms are reduced (e.g. Shimano et al., 2010, 2013; SouzA et al., 2011).

Therefore, our goal was to analyze how environmental factors and habitat integrity influence species richness, abundance, and functional group abundance of Leptophlebiidae in Cerrado streams. We tested the hypothesis that environmental integrity is more important than changes in water chemistry for mayflies.

\section{MATERIAL AND METHODS}

The Pindaíba River Basin (14¹6'46”S and $15^{\circ} 57^{\prime} 17^{\prime \prime} \mathrm{S} ; 51^{\circ} 26^{\prime} 37^{\prime \prime} \mathrm{W}$ and $52^{\circ} 37^{\prime} 03^{\prime \prime} \mathrm{W}$; $930 \mathrm{~m}$ a.s.l) has $10,029 \mathrm{~km}^{2}$ and is located in the eastern region of state 
of Mato Grosso, central Brazil. It is the major tributary of the right bank of the Rio das Mortes. Its headwaters are in the Acantilados plateau (BRASIL, 1981) in the city of Barra do Garças.

The climate in the region is Köppen's $C w a$, with two well-defined seasons: dry season between May and September and a rainy season between December and March. Annual average rainfall ranges from 1.200 to $1.600 \mathrm{~mm}$ and average temperatures from 20 to $25^{\circ} \mathrm{C}$, with September and October being the warmest months (BRASIL, 1981).

We sampled mayfly larvae in 16 sampling points of four $1^{\text {st }}$ to $4^{\text {th }}$ order streams (STRAHLER, 1957) (Fig. 1) on the left bank of the Pindaíba River: Cachoeirinha (CS), da Mata (MS), Papagaio (PS) and Taquaral (TS). Samplings were conducted in three periods of the year of 2005: January (peak of the rainy season), July (peak of the dry season) and October and November (early rainy season). We established $100-\mathrm{m}$ linear transects on the right bank in each sampling point. These transects were further divided into $205-\mathrm{m}$ segments (CABETTE et al., 2010; Dias-Silva et al., 2010; SHIMANo et al., 2012, 2013). Samples of the substrate were obtained through a sieve of $18 \mathrm{~cm}$ diameter and $250 \mu \mathrm{m}$ mesh, and were collected three times per segment.

Larvae were identified to the species or morphospecies level using taxonomic keys (DomíNGUEZ et al., 2006). Specimens were conserved in $85 \%$ ethanol and are housed at the zoobotanical collection James A. Ratter (CZNX, Universidade do Estado de Mato
Grosso). We classified each species/morphospecies into functional trophic group according to the literature (Bello \& Cabrera, 2001; Polegatto \& Froehlich, 2003; BAPTista et al., 2006; SHIMANo et al., 2012).

The environment integrity of each sampling point was measured by the protocol proposed by Nessimian et al. (2008). The protocol generates 12 variables about the local environment, including land use, the conservation status of the riparian zone, characteristics and morphology of streams. Each variable has four to six ordered levels according to integrity. The final index varies from zero (more impacted locals) to one (more conserved ones; Nessimiam et al., 2008).

Ten environmental variables were recorded: stream width (measured using Leica DISTOM ${ }^{\circledR}$ ); depth (measured using sonar Echotest ${ }^{\mathbb{R}}$ mod II); water temperature, $\mathrm{pH}$, turbidity, dissolved oxygen, conductivity (measured using $\mathrm{Horiba}^{\circledR}$ multiparameter probe); water hardness (measured using EDTA $0.002 \mathrm{M}$ ); nitrate and phosphorus (measured using spectrophotometer).

To test the influence of environmental variables on species abundance, richness, and abundance of Functional Feeding Groups (FFG) of Leptophlebiidae genera [Filtering Collectors (FC), shredder (S), and scrapers (SC)], simple linear regressions were used (ZAR, 1999).

To avoid multicollinearity among predictor variables, we calculated a pair-wise Pearson's correlation matrix between environmental variables. We removed variables with $r \geq 0.7$ (GRAHAM, 2003).

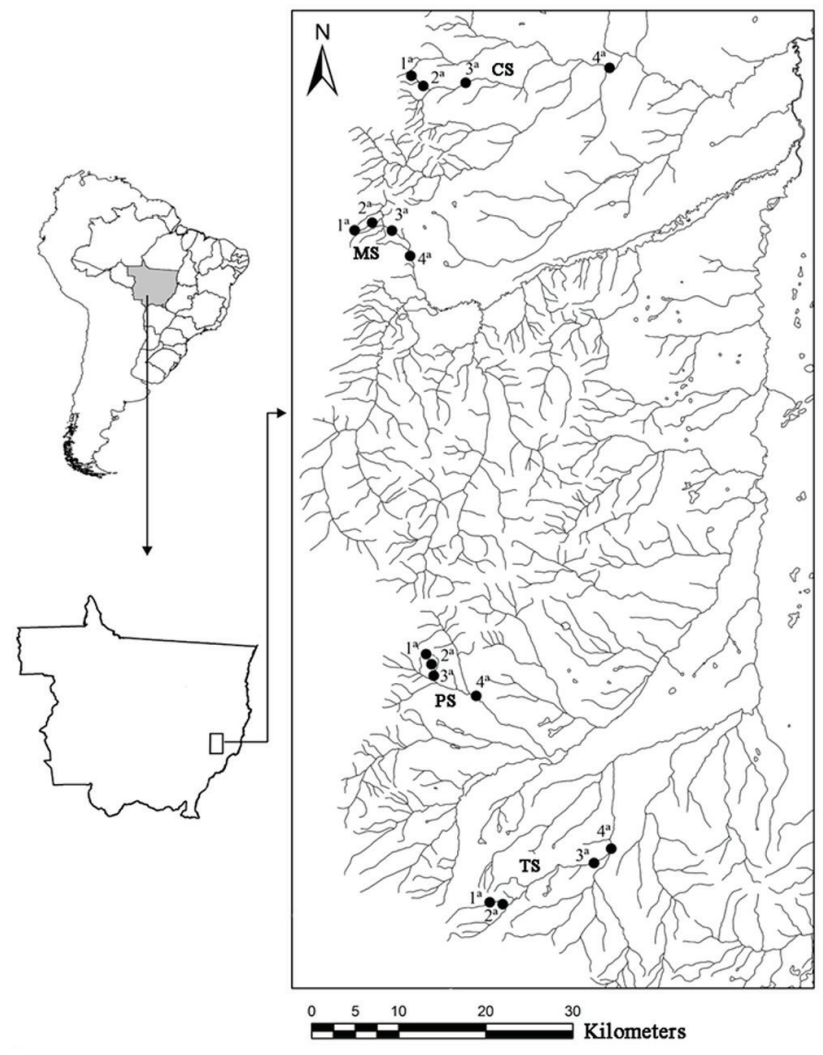

\begin{tabular}{cc}
\hline Abbreviations & Geographic coordinates \\
\hline CS1 & $14^{\circ} 50^{\prime} 30^{\prime \prime} \mathrm{S}, 52^{\circ} 24^{\prime} 54^{\prime \prime} \mathrm{W}$ \\
CS2 & $14^{\circ} 50^{\prime} 50^{\prime} \mathrm{S}, 52^{\circ} 24^{\prime} 22^{\prime \prime} \mathrm{W}$ \\
CS3 & $14^{\circ} 50^{\prime} 33^{\prime \prime} \mathrm{S}, 52^{\circ} 21^{\prime} 34^{\prime \prime} \mathrm{W}$ \\
CS4 & $14^{\circ} 49^{\prime} 45^{\prime \prime} \mathrm{S}, 52^{\circ} 12^{\prime} 55^{\prime \prime} \mathrm{W}$ \\
MS1 & $14^{\circ} 59^{\prime} 53^{\prime} \mathrm{S}, 52^{\circ} 28^{\prime} 42^{\prime \prime} \mathrm{W}$ \\
MS2 & $14^{\circ} 59^{\prime} 18^{\prime \prime} \mathrm{S}, 52^{\circ} 27^{\prime} 30^{\prime \prime} \mathrm{W}$ \\
MS3 & $14^{\circ} 59^{\prime} 59^{\prime \prime} \mathrm{S}, 52^{\circ} 26^{\prime} 29^{\prime \prime} \mathrm{W}$ \\
MS4 & $15^{\circ} 01^{\prime} 32^{\prime \prime} \mathrm{S}, 52^{\circ} 26^{\prime} 29^{\prime \prime} \mathrm{W}$ \\
PS1 & $15^{\circ} 27^{\prime} 01^{\prime \prime} \mathrm{S}, 52^{\circ} 24^{\prime} 30^{\prime \prime} \mathrm{W}$ \\
PS2 & $15^{\circ} 27^{\prime} 32^{\prime} \mathrm{S}, 52^{\circ} 24^{\prime} 42^{\prime \prime} \mathrm{W}$ \\
PS3 & $15^{\circ} 28^{\prime} 11^{\prime \prime} \mathrm{S}, 52^{\circ} 24^{\prime} 32^{\prime \prime} \mathrm{W}$ \\
PS4 & $15^{\circ} 28^{\prime} 59^{\prime \prime} \mathrm{S}, 52^{\circ} 21^{\prime} 47^{\prime \prime} \mathrm{W}$ \\
TS1 & $15^{\circ} 41^{\prime} 54^{\prime} \mathrm{S}, 52^{\circ} 20^{\prime} 03^{\prime \prime} \mathrm{W}$ \\
TS2 & $15^{\circ} 41^{\prime} 57^{\prime} \mathrm{S}, 52^{\circ} 19^{\prime} 56^{\prime \prime} \mathrm{W}$ \\
TS3 & $15^{\circ} 39^{\prime} 35^{\prime} \mathrm{S}, 52^{\circ} 13^{\prime} 52^{\prime \prime} \mathrm{W}$ \\
TS4 & $15^{\circ} 38^{\prime} 53^{\prime} \mathrm{S}, 52^{\circ} 12^{\prime} 53^{\prime \prime} \mathrm{W}$ \\
\hline
\end{tabular}

Fig. 1. Sampling sites of leptophlebiid larvae with geographic coordinates in four streams of Bioma Cerrado, Brazil: CS, Cachoeirinha stream; MS, da Mata stream; PS, Papagaio stream; TS, Taquaral stream. Roman numbers represent the stream order. 


\section{RESULTS}

We recorded 5,492 leptophlebiid larvae from 13 genera and 14 species (Tab. I). The most abundant species were Miroculis sp. $(\mathrm{n}=2,031)$ and Farrodes sp. $(n=1,353)$, comprising $61 \%$ of the total species abundance, followed by Terpides sooretamae Boldrini \&Salles, $2009(n=1,177)$ representing $21 \%$ of the total species abundance. The least abundant species were Tikuna bilineata (Needham \& Murphy, 1924) $(\mathrm{n}=2)$, Traverella sp. $(\mathrm{n}=17)$, and Simothraulopsis $\mathrm{sp} .(\mathrm{n}=25)$.

We found species belonging to three functional feeding groups: scrapers, filtering collectors, and shredders (Tab. I). Scrapers comprised seven genera and also had the highest abundance, with 3,760 species, representing $68.5 \%$ of the total abundance, and occurred in all sampling points (frequency 100\%). Shredders comprised four genera with $30.7 \%$ of the total abundance $(\mathrm{n}=1,684)$ and occurred in 14 sampling points $(87.5 \%)$. Filtering collectors included two genera, comprising $0.9 \%(n=48)$ of the total abundance and occurred in only seven sampling points $(46.8 \%)$.
The Habitat Integrity Index (HII) ranged from 0.61 to 0.96 . The less disturbed sites were Mata Stream 1 (MS1) with HII 0.96 and Taquaral Stream 1 (TS1) with 0.94 . The most disturbed sites were Taquaral Stream 3 (TS3) and Taquaral Stream 4 (TS4), both with 0.64, and Cachoeirinha Stream 1 (CS1) with 0.61 . We found that environmental variables did not explain species abundance and richness (Tab. II). Thus, it seems that the variance of these variables along sampling points could not predict mayfly community structure. However, the HII significantly influenced shredders' abundance $\left(\mathrm{R}^{2}=\right.$ $0.286 ; p=0.033$; Fig. 2 ), but not other functional groups (Tab. II).

\section{DISCUSSION}

Leptophlebiidae is a speciose taxa, with several generalist genera widespread in aquatic ecosystems (DomínguEZ et al., 2006). Here, we presented relevant data about the distribution and ecology of 14 mayfly species. Most information about the ecology of leptophlebiids in Brazil are sparse and anecdotal (DA-

Tab. I. Abundance and frequency of leptophlebiid larvae in four streams of Bioma Cerrado, Brazil (CS, Cachoeirinha stream; MS, da Mata stream; PS, Papagaio stream; TS, Taquaral stream).

\begin{tabular}{|c|c|c|c|c|c|c|c|c|c|c|c|c|c|c|c|c|c|}
\hline & \multicolumn{4}{|c|}{$\mathrm{CS}$} & \multicolumn{4}{|c|}{ MS } & \multicolumn{4}{|c|}{ PS } & \multicolumn{4}{|c|}{ TS } & \multirow{2}{*}{$\frac{\text { Frequency }}{\%}$} \\
\hline & $1^{\mathrm{a}} \mathrm{O}$ & $2^{\mathrm{a}} \mathrm{O}$ & $3^{\mathrm{a}} \mathrm{O}$ & $4^{\mathrm{a} O}$ & $1^{\mathrm{a} O}$ & $2^{\mathrm{a} O}$ & $3^{\mathrm{a} O}$ & $4^{\mathrm{a} O}$ & $1^{\mathrm{a}} \mathrm{O}$ & $2^{\mathrm{a} O}$ & $3^{\mathrm{a} O}$ & $4^{\mathrm{a} O}$ & $1^{\mathrm{a}} \mathrm{O}$ & $2^{\mathrm{a} O}$ & $3^{\mathrm{a} O}$ & $4^{\mathrm{a} O}$ & \\
\hline Askola sp. & 0 & 2 & 18 & 0 & 0 & 5 & 0 & 2 & 7 & 3 & 3 & 0 & 1 & 6 & 0 & 0 & 56.2 \\
\hline Farrodes sp. & 3 & 218 & 70 & 5 & 35 & 172 & 196 & 161 & 124 & 122 & 126 & 15 & 58 & 9 & 31 & 11 & 100.0 \\
\hline Fittkaulus cururuensis Savage, 1986 & 1 & 38 & 19 & 0 & 0 & 1 & 20 & 19 & 1 & 6 & 4 & 23 & 32 & 7 & 0 & 3 & 81.3 \\
\hline Gênero 4 sp. & 0 & 8 & 0 & 0 & 4 & 0 & 6 & 0 & 12 & 3 & 20 & 0 & 29 & 1 & 0 & 0 & 50.0 \\
\hline Hagenulopsis sp. & 0 & 4 & 90 & 0 & 6 & 5 & 9 & 2 & 45 & 12 & 6 & 0 & 3 & 9 & 0 & 0 & 68.8 \\
\hline Miroculis sp. & 61 & 506 & 391 & 0 & 2 & 18 & 174 & 62 & 0 & 25 & 115 & 54 & 31 & 266 & 111 & 215 & 87.5 \\
\hline Paramaka convexa (Spieth, 1943) & 0 & 0 & 9 & 0 & 0 & 0 & 2 & 0 & 0 & 1 & 2 & 0 & 1 & 0 & 9 & 7 & 43.85 \\
\hline Simothraulopsis sp. & 0 & 0 & 0 & 0 & 1 & 1 & 8 & 3 & 2 & 1 & 1 & 1 & 0 & 0 & 2 & 7 & 62.5 \\
\hline $\begin{array}{l}\text { Terpides sooretame Boldrini \& } \\
\quad \text { Salles, } 2009\end{array}$ & 1 & 8 & 4 & 0 & 0 & 122 & 325 & 100 & 94 & 16 & 73 & 4 & 388 & 42 & 0 & 0 & 75.0 \\
\hline Thraulodes sp. & 0 & 0 & 0 & 0 & 0 & 0 & 0 & 0 & 20 & 4 & 0 & 0 & 1 & 0 & 0 & 0 & 87.5 \\
\hline $\begin{array}{l}\text { Tikuna bilineata } \text { (Needham \& } \\
\text { Murphy, 1924) }\end{array}$ & 0 & 0 & 0 & 0 & 0 & 0 & 0 & 0 & 0 & 0 & 0 & 0 & 0 & 0 & 1 & 1 & 12.5 \\
\hline Traverella $\mathrm{sp}$ & 0 & 0 & 0 & 0 & 0 & 0 & 0 & 0 & 0 & 0 & 0 & 0 & 0 & 0 & 15 & 2 & 12.5 \\
\hline Ulmeritoides sp. 2 & 8 & 8 & 5 & 0 & 0 & 3 & 32 & 9 & 0 & 1 & 2 & 17 & 6 & 19 & 15 & 13 & 81.3 \\
\hline Ulmeritoides sp. 3 & 52 & 22 & 7 & 0 & 0 & 1 & 19 & 21 & 0 & 0 & 1 & 1 & 20 & 47 & 1 & 1 & 75.0 \\
\hline Abundance by sites & 126 & 814 & 613 & 5 & 48 & 328 & 791 & 379 & 305 & 194 & 353 & 115 & 570 & 406 & 185 & 260 & $100 \%$ \\
\hline
\end{tabular}

Tab. II. Functional Trophic Groups (FTG) of leptophlebiid genera of four streams of Bioma Cerrado, Brazil (FC, filtering collectors; S, shredder; $\mathrm{SC}$, scrapers) and references consulted.

\begin{tabular}{|c|c|c|}
\hline Genera & FTG & References consulted \\
\hline Askola Peters, 1969 & $\mathrm{SC}$ & Polegatto \& Froehlich, 2003; Baptista et al., 2006 \\
\hline Farrodes Peters, 1971 & $\mathrm{SC}$ & Polegatto \& Froehlich, 2003; Siegloch, 2006; Baptista et al., 2006 \\
\hline Fittkaulus Savage \& Peters, 1978 & $\mathrm{~S}$ & Inference to Terpides \\
\hline Gênero 1 & $\mathrm{SC}$ & Inference to Farrodes \\
\hline Hagenulopsis Ulmer, 1920 & $\mathrm{SC}$ & BAPTISTA et al., 2006 \\
\hline Miroculis Edmunds, 1963 & $\mathrm{SC}$ & Polegatto \& Froehlich, 2003 \\
\hline Paramaka Savage \& Domínguez, 1992 & $\mathrm{FC}$ & SALLES, 2006 \\
\hline Simothraulopsis Demoulin, 1966 & $\mathrm{SC}$ & Polegatto \& Froehlich, 2003 \\
\hline Terpides Demoulin, 1966 & $\mathrm{~S}$ & BeLlo \& CABRERA, 2001 \\
\hline Thraulodes Ulmer, 1920 & $\mathrm{SC}$ & Polegatto \& Froehlich, 2003 \\
\hline Tikuna Savage, Flowers \& Porras, 2005 & $\mathrm{~S}$ & Inference to Terpides \\
\hline Traverella Ednunds, 1948 & $\mathrm{FC}$ & Polegatto \& Froelich, 2003 \\
\hline Ulmeritoides Traver, 1959 & $\mathrm{~S}$ & SHIMANO et al., 2011 \\
\hline
\end{tabular}




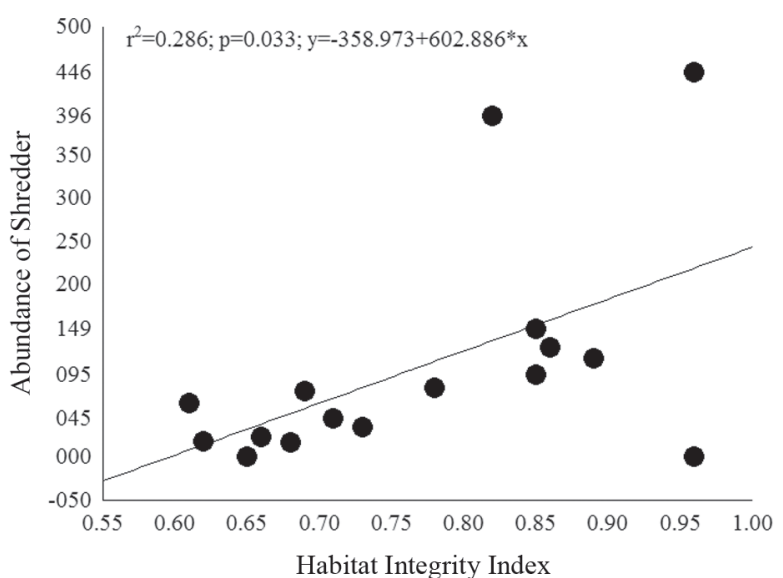

Fig. 2. Relationship between abundance of shredders and Habiat Integrity Index (IIH) in four streams of Bioma Cerrado, Brazil (CS, Cachoeirinha stream; MS, da Mata stream; PS, Papagaio stream; TS, Taquaral stream).

Silva et al., 2010). A recent study (Shimano et al., 2012) provided information about the distribution of functional groups of mayflies. However, the same study did not investigate the influence of environmental and anthropogenic factors on the community.

The dominance of scrapers is related to the high abundance of Miroculis and Farrodes. Both genera are known for their wide geographic ranges and generalist habits, inhabiting most aquatic environments (Domínguez et al., 2002; BAPTISTA et al., 2006), including the semi-lotic ones (DA-SiLVA et al., 2002). Likely, these morphospecies may constitute more than one species, since it is difficult to identify their larvae to the specific level (SHImano et al., 2010).

Although Farrodes is commonly classified as a scraper (Bello \& Cabrera, 2001; Polegatto \& Froehlich, 2003; Baptista et al., 2006; Shimano et al., 2011), they are opportunist feeders and likely use a wider range of food sources (ANDERSON \& SEDELL, 1979; Bello \& CABRERA, 2001). For example, a species of Farrodes was classified as filtering collectors (Polegatto \& Froenlich, 2003). Filtering-collectors had the lowest abundance in our study. There is no natural history information about the two species recorded, but they only occurred in medium-sized streams $\left(3^{\text {rd }}\right.$ and $4^{\text {th }}$ orders). The same result was found by Shimano et al. (2010), in the Suiá-Miçú river basin regarding Paramaka convexa (Spieth, 1943).

Shredders were highly abundant, mainly due to the poorly-known species Terpides sooretame, which represented $87 \%$ of the shredder abundance. It is only known that it has a wide geographic range within the drainage basin in Mato Grosso (Shimano et al., 2011). With the records of Fittkaulus and the rare Tikuna, the Pindaíba River basin now holds three genera of the Terpides lineage (BondRINI et al., 2009). Shredders feed on allochthonous plant material (CUmmins \& KLUG, 1979; VANNOTE et al., 1980), contributing to the primary production though. Shredders were also the organisms that were affected by environmental disturbances. Despite the relatively low correlation, the relationship between HII and shedder abundance is an important result, since the fragmentation is an important function of ecosystem of small streams. This result corroborates in part our hypothesis that environmental integrity affects mayflies more than physico-chemical parameters.

The HII index takes into account land use patterns, the conservation status of both riparian vegetation and stream channel (NESSIMIAN et al., 2008). Most sampling sites stood as medium highly conserved. However, the small changes affected significantly the abundance of shredders. These organisms play key roles in energy cycling in headwaters (Allan \& CASTILLO, 2007).

The riparian vegetation plays a key functional and ecological role, silizing stream banks and providing structural heterogeneity (RUPPENTHAL et al., 2007). Therefore, the loss of riparian vegetation in springs and headwaters has profound consequences for the aquatic

Tab. III. Mean values of environmental variables in four streams of Bioma Cerrado, Brazil (CS, Cachoeirinha stream; MS, da Mata stream; PS, Papagaio stream; TS, Taquaral stream).

\begin{tabular}{lcccccccc}
\hline Local & $\mathrm{pH}$ & Conductivity & Turbidity & Temperature & Dissolved oxygen & Phosphorus & Width & HII \\
\hline CS1 & 6.65 & 100.75 & 31.95 & 21.75 & 3.10 & 0.16 & 1.93 & 0.61 \\
CS2 & 6.33 & 54.57 & 26.56 & 23.83 & 3.10 & 0.15 & 2.33 & 0.69 \\
CS3 & 6.17 & 13.57 & 21.58 & 24.03 & 5.92 & 0.19 & 3.28 & 0.73 \\
CS4 & 6.66 & 7.50 & 19.63 & 23.58 & 6.76 & 0.12 & 7.91 & 0.65 \\
MS1 & 6.38 & 0.30 & 1.60 & 25.03 & 7.33 & 0.06 & 1.08 & 0.96 \\
MS2 & 5.93 & 0.57 & 2.27 & 24.17 & 6.68 & 0.04 & 1.07 & 0.86 \\
MS3 & 6.51 & 3.03 & 35.67 & 23.27 & 8.32 & 0.14 & 4.82 & 0.82 \\
MS4 & 6.64 & 7.00 & 21.41 & 23.55 & 6.93 & 0.12 & 10.87 & 0.85 \\
PS1 & 7.03 & 14.30 & 2.95 & 24.27 & 6.20 & 0.16 & 2.96 & 0.85 \\
PS2 & 6.80 & 18.97 & 6.89 & 23.80 & 6.10 & 0.16 & 2.53 & 0.66 \\
PS3 & 6.80 & 11.97 & 3.60 & 23.90 & 5.20 & 0.10 & 6.13 & 0.78 \\
PS4 & 6.61 & 6.01 & 24.98 & 23.48 & 7.28 & 0.13 & 4.74 & 0.71 \\
TS1 & 6.71 & 7.30 & 2.28 & 24.65 & 6.77 & 0.11 & 1.36 & 0.94 \\
TS2 & 6.37 & 9.77 & 4.58 & 23.98 & 6.39 & 0.10 & 6.00 & 0.83 \\
TS3 & 6.66 & 7.50 & 19.63 & 23.58 & 6.76 & 0.12 & 5.42 & 0.64 \\
TS4 & 6.64 & 6.84 & 22.01 & 23.54 & 6.99 & 0.12 & 8.09 & 0.64 \\
\hline
\end{tabular}


Tab. IV. Results of linear regression between species abundance, richness, and abundances of functional trophic groups of leptophlebiid genera in four streams of Bioma Cerrado, Brazil (FC, filtering collectors; S, shredder; SC, scrapers) and environmental variables. ${ }^{*} P<0.05$.

\begin{tabular}{|c|c|c|c|c|c|c|c|c|c|c|}
\hline & \multicolumn{5}{|c|}{ Values of $\mathrm{r}^{2}$} & \multicolumn{5}{|c|}{ Values of $p$} \\
\hline & Abundance & Richness & $\mathrm{SC}$ & $\mathrm{S}$ & FF & Abundance & Richness & $\mathrm{SC}$ & $\mathrm{S}$ & FF \\
\hline $\mathrm{pH}$ & 0.08 & 0.01 & 0.15 & 0.00 & 0.00 & 0.28 & 0.71 & 0.14 & 0.92 & 0.94 \\
\hline Conductivity & 0.00 & 0.01 & 0.02 & 0.02 & 0.03 & 0.93 & 0.68 & 0.61 & 0.58 & 0.55 \\
\hline Turbidity & 0.05 & 0.07 & 0.08 & 0.00 & 0.03 & 0.39 & 0.31 & 0.30 & 0.95 & 0.49 \\
\hline Temperature & 0.01 & 0.01 & 0.01 & 0.01 & 0.00 & 0.68 & 0.78 & 0.79 & 0.69 & 0.81 \\
\hline Dissolved oxygen & 0.02 & 0.00 & 0.13 & 0.08 & 0.02 & 0.63 & 1.00 & 0.17 & 0.30 & 0.60 \\
\hline Phosphorus & 0.08 & 0.00 & 0.14 & 0.00 & 0.02 & 0.29 & 0.99 & 0.15 & 0.90 & 0.63 \\
\hline Width & 0.06 & 0.06 & 0.03 & 0.04 & 0.04 & 0.36 & 0.36 & 0.51 & 0.46 & 0.47 \\
\hline HII & 0.05 & 0.00 & 0.00 & 0.29 & 0.11 & 0.39 & 0.92 & 0.83 & $* 0.03$ & 0.21 \\
\hline
\end{tabular}

food web and the maintenance of ecosystem processes (Allan, 2004; Allan \& CASTILlo, 2007).

Our results about the influence of environmental variables on the species richness and abundance support the findings of other studies with different aquatic insects (Nessimian et al., 2008; Dias-Silva et al., 2010; Nogueira et al., 2011). This result could be due to: (i) each water chemistry variable may have not significant relationships with community structure (CABETTE et al., 2010), and (ii) the larvae of aquatic insects can tolerate the wide variation in water chemistry (DiAs-SiLVA et al., 2010), since Cerrado streams face prolonged dry and rainy seasons, with multiple flood pulses in the latter. The lack of relationship between HII and abundance and species richness of other functional feeding groups may be related to the characteristics of sampled streams. Even the altered streams kept remnants of riparian forest in one of the margins.

Water chemistry variables did not influence species richness, abundance, and richness of functional feeding groups of Leptophlebiidae. However, shredders were significantly affected by changes in habitat quality. The decrease in shredder abundance can probably disturb nutrient cycling. The effects of these changes will better understood when we analyze the relationships between functional groups and the HII than only species richness. This study added relevant information about the species and functional groups of Ephemeroptera that could be useful for the monitoring and conservation of streams in the Cerrado.

Acknowledgements. This study was funded by the Fundação de Amparo à Pesquisa do Estado de Mato Grosso (\#098/04) and CAPES/PROCAD (\#109/2007). LSB and JDB received fellowships from CNPq (PELD \#558069/2009-6). Lorivaldo A. Castro provided logistics during field work. Frederico F. Salles helped in species identification. Diogo B. Provete reviewed the English language. Several undergrad students from UNEMAT helped in fieldwork.

\section{REFERENCES}

Agostinho, A. A.; Thomaz, S. M. \& Gomes, L. C. 2005 Conservação da biodiversidade em águas continentais do Brasil. Megadiversidade 1(3):70-78.

Allan, J. D. 2004. Landscapes and riverscapes: the influence of land use on stream ecosystems. Annual Review of Ecology, Evolution, and Systematics 35:257-284.

Allan, J. D. \& CASTILlo, M. M. 2007. Stream ecology: structure and function of running waters. Dordrecht, Springer. 436p. Anderson, N. H. \& Sedell, J. R. 1979. Detritus processing by macroinvertebrates in stream ecosystems. Annual Review of Entomology 24:351-377.

Bae, Y. J.; Kwon, S. H.; Chon, T.; Yang, H.; Kwak, I.; Park, J.; HAM, S. \& PARK, Y. 2011. Relationships between three major stream assemblagesand their environmental factors in multiple spatial scales. Annales de Limnologie -International Journal of Limnology 47:91-105.

Baptista, D. F.; Buss, D. F.; Nessimian, J. L.; Da Silva, E. R.; De Moraes Neto, A. H. A.; Carvalho, S. N.; De Oliveira, M. A. \& ANDRADE, L. R. 2006. Diversity and habitat preference of aquatic insect along the longitudinal gradient of the Macaé River BASIN, Rio de Janeiro, Brasil. Revista Brasileira de Biologia 61(2):249258.

Bello, C. L. \& Cabrera, M. I. 2001. Alimentación ninfal de Leptophlebiidae (Insecta: Ephemeroptera) en el Caño Paso del Diablo, Venezuela. Revista de Biologia Tropical 49(3-4):9991003.

Boldrini, R.; Salles, F. F. \& Cabette, H. S. R. 2009. Contribution to the taxonomy of the Terpides lineage (Ephemeroptera: Leptophlebiidae). Annales de Limnologie - International Journal of Limnology 45:219-229.

Brasil. 1981. Projeto RADAMBRASIL, Folha SD 22. Goiás: geologia, geomorfologia, pedologia, vegetação, uso potencial da terra. Brasília, Ministério das Minas e Energia/Divisão de Publicação. 636p.

Brittain, J. E. 1982. Biology of mayflies. Annual Review of Entomology 27:119-147.

Cabette, H. S. R.; Giehl, N. F. S.; Dias-silva, K.; Juen, L. \& Batista, J. D. 2010. Distribuição de Nepomorpha e Gerromorpha (Insecta: Heteroptera) da Bacia Hidrográfica do Rio Suiá-Miçu, MT: riqueza relacionada a qualidade da água e do hábitat. In: SANTOS J. E.; Galbiati, C. \& Mochini, L. E. eds. Gestão e educação ambiental. Cáceres, Universidade do Estado de Mato Grosso, v. 2. p. 113-137.

Cummins, K. W. \& Klug, M. J. 1979. Feeding ecology of stream invertebrates. Annual Review of Ecology, Evolution, and Systematics 10:147-172.

Da-Silva, A. N. \& Domingues, P. 2009. Bioindicadores aquáticos continentais. Saúde \& Ambiente em Revista 4(2):87-93.

Da-Silva, E. R.; Nessimian, J. L. \& Coelho, L. B. N. 2010. Leptophlebiidae ocorrentes no Estado do Rio de Janeiro, Brasil: hábitats, meso-hábitats e hábitos das ninfas (Insecta: Ephemeroptera). Biota Neotropica 10(4):87-94.

DA-SilVA, E. R.; SALLES, F. F. \& BAPTISTA, M. S. 2002. As brânquias dos gêneros de Leptophlebiidae (Insecta: Ephemeroptera) ocorrentes no Estado do Rio de Janeiro. Biota Neotropica 2(2):1-4.

Delong, M. D. \& Brusven, M. A. 1994. Allochthonous input of organic matter from different riparian habitats of an agriculturally impacted stream. Environmental Management 18(1):59-71.

Dias-Silva, K.; Cabette, H. S. R.; Juen, L. \& De Marco, P. 2010. The influence of habitat integrity and physical-chemical water variables on the structure of aquatic and semi-aquatic Heteroptera. Zoologia 27(6):918-930.

Domínguez, E.; Molineri, C.; Pescador, M. L.; Hubbard, M. \& Nieto, C. 2006. Ephemeroptera of South America. Pensoft, Moscow. 646p.

Domínguez, E.; Zuniga, M. C. \& Molineri, C. 2002. Estado actual 
del conocimiento y distribución del Orden Ephemeroptera (Insecta) en la región Amazónica. Caldasia 24(2):379-391.

Graham, M. H. 2003. Confronting multicollinearity in ecological multiple regression. Ecology 84:2809-2815.

Nessimian, J. L.; Venticingue, E. M.; Zuanon, J.; De Marco, P. JR.; Gordo, M.; Fidelis, L.; Batista, J. D. \& Juen, L. 2008. Land use, habitat integrity, and aquatic insect assemblages in Central Amazonian streams. Hydrobiologia 614:117-131

Nogueira, D. S.; Cabette, H. S. R. \& Juen, L. 2011. Estrutura e composição da comunidade de Trichoptera (Insecta) de rios e áreas alagadas da bacia do rio Suiá-Miçú, Mato Grosso, Brasil. Iheringia, Série Zoologia 101(3):173-180.

Polegatto, C. M. \& Batista, J. D. 2007. Hydromastodon sallesi, new genus and new species of Atalophlebiinae (Insecta: Ephemeroptera: Leptophlebiidae) from West and North of Brazil, and notes on systematics of Hermanella group. Zootaxa 1619:5360.

Polegatto, C. M. \& Froehlich, C. G. 2003. Feeding strategies in Atalophlebiinae (Ephemeroptera: Leptophlebiidae), with considerations on scraping and filtering. Research Update on Ephemeroptera \& Plecoptera:55-61. Available at: <http://www. ephemeropteragalactica.com/pubs/pub_p/pubpolegattoc2003p55. pdf $>$. Accessed on 17 September 2013.

Ruppenthal, E. L.; Nin, C. S. \& Rodrigues, G. G. 2007. A mata ciliar/curso d'água é um ecossistema único? Revista Brasileira de Biociências 5(1):525-527.

Salles, F. F.; Boldirini, R.; Nascimento, J. M. C.; Angeli, K. B.; Massariol, F. C. \& Raimundi, E. 2013. Ephemeroptera do Brasil. Available at: <http://ephemeroptera.com.br/>. Accessed on: 3 August 2013.

Salles, F. F.; Da-Silva, E. R.; Hubbard, M. D. \& Serrão, J. E. 2004. As espécies de Ephemeroptera (Insecta) registradas para o Brasil.
Biota Neotropica 4(2):1-34.

Shimano, Y.; Cabette, H. S. R.; Salles, F. F. \& Juen, L. 2010 Composição e distribuição da fauna de Ephemeroptera (Insecta) em área de transição Cerrado-Amazônia, Brasil. Iheringia, Série Zoologia 100(4):301-308.

Shimano, Y.; Juen, L.; Salles, F. F.; Nogueira, D. S. \& Cabette, H. S. R. 2013. Environmental and spatial processes determining Ephemeroptera (Insecta) structures in tropical streams. Annales de Limnologie - International Journal of Limnology 49:31-41.

Shimano, Y.; Salles, F. F. \& Cabette, H. S. R. 2011. Ephemeroptera (Insecta) ocorrentes no Leste do Estado do Mato Grosso, Brasil. Biota Neotropica 11:239-253.

Shimano, Y.; Salles, F. F.; Faria, L. R. R.; Cabette, H. S. R. \& NogueIRA, D. S. 2012. Distribuição espacial das guildas tróficas e estruturação da comunidade de Ephemeroptera (Insecta) em córregos de Cerrado de Mato Grosso, Brasil. Iheringia, Série Zoologia 102(2):187-196.

Souza, H. M. S.; Cabette, H. S. R. \& Juen, L. 2011. Baetidae (Insecta, Ephemeroptera) em córregos do cerrado matogrossense sob diferentes níveis de preservação ambiental. Iheringia, Série Zoologia 101(3): 181-190.

STRAHLER, H. N. 1957. Quantitative analysis of watershed geomorphology. American Geophysical Union Transactions 33:913-920.

Tate, C. M. \& Heiny, J. S. 1995. The ordination of benthic invertebrate communities in the South Platte River Basin in relation to environmental factors. Freshwater Biology 33(3):439-454.

Vannote, R. L.; Minshall, G. W.; Cummins, K. W.; Sedell, J. R. \& Cushing, C. E. 1980. The river continuum concept. Canadian Journal of Fisheries and Aquatic Sciences 37(1):130-137.

ZAR, J. H. 1999. Biostatistical Analysis. Englewood Cliffs, Prentice Hall. 663p.

Received 3 April 2013. Accepted 25 September 2013. ISSN 0073-4721

Article available at: www.scielo.br/isz 